\title{
Multivariate Analysis of the Brinell Hardness of Silver Birch (Betula pendula Roth.) Wood in Poland
}

\author{
Hubert Lachowicz ${ }^{1}$, Rafał Wojtan ${ }^{2}{ }^{\mathbb{D}}$, Antons Seleznovs ${ }^{3}$, Jānis Lāceklis-Bertmanis ${ }^{4}$, Aivars Kaḳīis ${ }^{5}$ \\ and Aleksandra Krystyna Giedrowicz 1,*:D \\ 1 Department of Forest Utilization, Warsaw University of Life Sciences (SGGW), Nowoursynowska Str. 159, \\ 02-776 Warsaw, Poland; hubert_lachowicz@sggw.edu.pl \\ 2 Department of Forest Management Planning, Dendrometry and Forest Economics, Warsaw University of Life \\ Sciences (SGGW), Nowoursynowska Str. 159, 02-776 Warsaw, Poland; rafal_wojtan@sggw.edu.pl \\ 3 Riga City Forests, Jurmalas gatve 78D, LV-1029 Riga, Latvia; anton.se1008@gmail.com \\ 4 Institute of Motor Vehicle, Faculty of Engineering, Latvia University of Life Sciences and Technologies, \\ J. Cakstes Blvd. 5, LV-3001 Jelgava, Latvia; janis.laceklis@llu.lv \\ 5 Institute of Mechanics, Faculty of Engineering, Latvia University of Life Sciences and Technologies, \\ J. Cakstes Blvd. 5, LV-3001 Jelgava, Latvia; aivars.kakitis@llu.lv \\ * Correspondence: aleksandra_giedrowicz@sggw.edu.pl
}

Citation: Lachowicz, H.; Wojtan, R.; Seleznovs, A.; Lāceklis-Bertmanis, J.; Kakītis, A.; Giedrowicz, A.K.

Multivariate Analysis of the Brinell Hardness of Silver Birch (Betula pendula Roth.) Wood in Poland. Forests 2021, 12, 1308.

https://doi.org/10.3390/f12101308

Academic Editor: Marcin Jakubowski

Received: 13 September 2021

Accepted: 23 September 2021

Published: 25 September 2021

Publisher's Note: MDPI stays neutral with regard to jurisdictional claims in published maps and institutional affiliations.

\begin{abstract}
An analysis was undertaken of the Brinell hardness of silver birch wood and its dependence on stand location, tree age, tree thickness and forest habitat type, and the interactions between these factors. Wood was obtained from 12 forest districts throughout Poland, from trees aged approximately 30, 50, and 70 years. A total of 51 study plots was established, from which 306 trees were taken. Hardness was measured on three surfaces (transverse, radial, and tangential sections) for 4777 samples, giving a total of 14,331 measurements. It was shown that the hardness of silver birch wood in Poland is significantly influenced by location, tree age, tree thickness, and habitat type, and by interactions between those factors. Habitat type was not shown to affect radial hardness, except in the case of Giżycko forest district. For the whole of the analysed material, the mean hardness on a transverse section was calculated as $66.26 \mathrm{MPa}$, corresponding to a very hard wood on Mörath's scale, whereas the values for the longitudinal sections (radial 44.06 $\mathrm{MPa}$, tangential 44.02 $\mathrm{MPa}$ ) correspond to a soft wood.
\end{abstract}

Keywords: brinell hardness; tree age; forest habitat type; tree thickness; geographical location; wood technical quality; wood mechanical properties

\section{Introduction}

The hardness of wood is an important strength parameter. It is particularly significant for machining processes, and affects the durability of elements subject to abrasive action $[1,2]$. The first definition of hardness was given by Heinrich R. Hertz [3], who defined it as the force pressing two spheres that would cause their plastic deformation. Later, hardness was defined as the resistance encountered by a foreign body attempting to penetrate the anatomical structure of the wood [4]; as the resistance provided by the wood material on working with tools [5]; as the resistance provided by a material to bodies being pressed into its surface, expressed in $\mathrm{kG} \cdot \mathrm{cm}^{-2}$ or $\mathrm{kG} \cdot \mathrm{mm}^{-2}$ [6]; or as the resistance of a material to permanent deformations under the action of concentrated forces acting on a small surface area of the material [7]. At present, hardness is measured as the resistance provided by a body when an indenter is pressed into it, with regard to plastic deformations [1]. The hardness of a material is not as unambiguous as, for example, its strength or modulus of elasticity. Multiple tests and scales have been developed for the measurement of hardness. Indenters of different shapes are used depending on the hardness of the tested material. The round shape used in the methods of Brinell, Janka, Krippel, and Meyer is significantly 
better for the testing of wood than, for instance, the conical shape used in Rockwell's method [8]. The measurement of hardness by Brinell's method is a standard test for determining a floor's resistance to indentation [9], and Doyle and Walker [10] report it to be the most frequently applied method in materials science. They note, however, that the precise measurement of the size of a permanent indentation is problematic, particularly when a large ball is used. Given the non-uniform structure of wood, a distinction must be made between hardness on longitudinal and transverse sections. Hardness also depends on the dryness of the wood $[1,6,8]$. A drop in water content causes an increase in hardness, and when the moisture content is less than $8 \%$ the wood becomes so brittle that it is not possible to measure its hardness. For this reason, wood hardness is determined at a moisture content above $8 \%$ [11]. Studies have also been conducted of how the hardness of wood is affected by various modifications, including compaction of the wood [12,13], thermal treatment [14-16] and chemical treatment [17]. The impact of the felling season, drying method, and distance from the core has also been investigated [18] However, there is little available information on the dependence of hardness on geographical location, forest habitat type, tree age or tree thickness. Klisz et al. [19] report that age has an impact on the hardness of birch wood.

Birch is among the most economically important tree species in Europe [20]. In Poland it is the most important broad-leaved species. It currently covers $7.3 \%$ of the total forest area, and accounts for a greater share in privately owned forests. The largest birch stands are located in Warmińsko-mazurskie province, and the smallest in Małopolskie [21]. Birch wood is easily worked, and its physical and mechanical properties make it suitable for use in the cellulose and paper industry, in the production of plywood and veneer, and in furniture and flooring [20]. A pilot study was carried out in forests of fresh broad-leaved type (FBF) in northeast Poland concerning selected structural, physical, and mechanical properties of silver birch wood and their dependence on geographical location, tree age (approximately 50 and 70 years), and tree thickness. This provided a broad foundation for conducting the current research on silver birch wood according to the same methodology. The result of this is a database describing, in the most extensive manner to date, the variation in certain properties of birch wood in Poland, these properties being important determiners of the technical quality of the wood. Of many completed studies, results have recently been published concerning the elementary structure, fuel properties, chemical composition and density of silver birch wood as functions of selected factors; these show that stand location, habitat type, tree age, and tree thickness have a significant impact on most of the studied parameters [22-25]. No previous studies have been carried out to determine the effect of geographical location, tree age, tree thickness and habitat type on hardness values of silver birch wood from the whole of Poland. The following analyses complement the comprehensive studies of the technical properties of silver birch wood growing in Poland, and may guide the future commercial use of this raw material.

The aim of this work was to test the following hypothesis: values of the Brinell hardness of the wood of silver birch (Betula pendula Roth.) are significantly dependent on the geographical location of the stand, tree age, tree thickness, and forest habitat type, and interactions between these factors. The results obtained for hardness on a transverse section indicate that Polish birch wood can be classified as a very hard wood.

\section{Materials and Methods}

\subsection{Study Site}

All tests of the properties of silver birch wood were carried out on material obtained from study plots established in the main commercial growing regions of this species in Poland.

Studies were carried out in stands belonging to the Polish State Forestry Board (PGL LP). Birch trees aged approximately 30, 50 and 70 years were selected in stands of the fresh broad-leaved (FBF) and fresh mixed broad-leaved (FMBF) forest habitat types. These are the two habitat types in Poland where birch stands are most prevalent in terms of 
area and wood volume [23]. A description of these habitats can be found in previous publications [22,24]. The studies were carried out in 12 forest districts distributed across the country, using trees in three age categories (approximately 30, 50 and 70 years), in the habitat type FBF, and in some districts also FMBF (Figure 1). In total, field studies were conducted in 51 study plots.

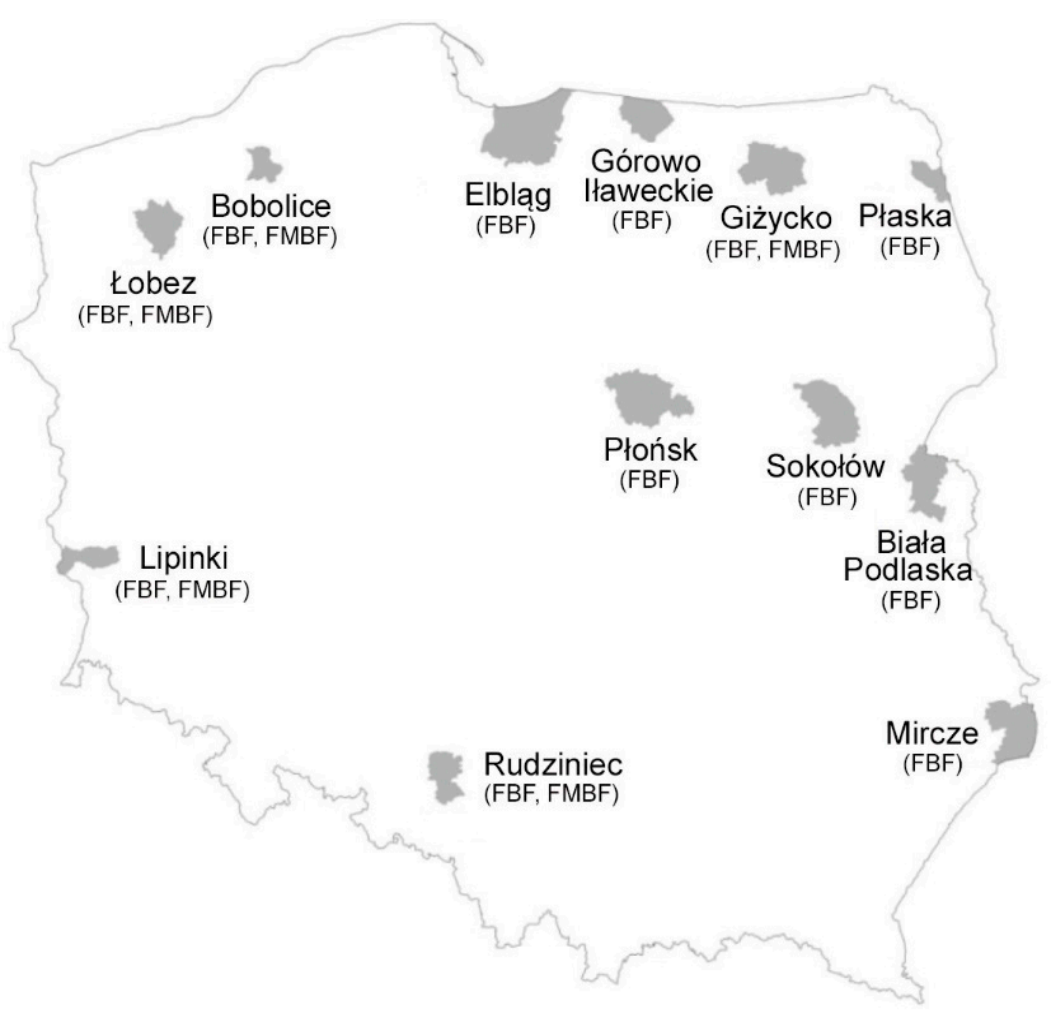

Figure 1. Geographical distribution of the forest districts where the test plots were located [26].

\subsection{Sampling and Analysis}

In the study plots, measurements were made of the diameter at breast height of all trees for which this exceeded $7 \mathrm{~cm}$. Sample trees were selected on the study plots by Hartig's method, based on the mean cross-sectional area at breast height, with trees assigned to three thickness classes: the thinnest trees (class 1), trees of medium thickness (class 2) and the thickest trees (class 3) [27,28].

Two trees from each thickness class were selected and felled, giving a total of six trees from each plot. In total, study material was taken from 306 trees. After felling, from the part of each tree around breast height, two or three $50 \mathrm{~cm}$ long sections were taken (from a breast height of $1.3 \mathrm{~m}: 50 \mathrm{~cm}$ towards the root and $50-100 \mathrm{~cm}$ towards the crown). These were cut into split logs and appropriately labelled. Following seasoning, and when the moisture content of the wood was approximately $15 \%$, samples were cut with dimensions $20(\mathrm{~T}) \times 20(\mathrm{R}) \times 30(\mathrm{~L}) \mathrm{mm}$.

The hardness of the silver birch wood was determined for a population of 4777 samples, in each anatomical direction, according to the following formula:

$$
H B=\frac{2 P}{D \pi\left(D-\sqrt{\left.D^{2}-d^{2}\right)}\right.}
$$

where:

$H B$ is the Brinell hardness of the wood [MPa];

$P$ is the pressing force on the indenter $[\mathrm{N}]$;

$D$ is the diameter of the indenter [mm]; 
$d$ is the mean diameter of the indentation [mm].

In Brinell's method of hardness measurement, a spherical indenter made of hardened steel is pressed into the surface of the material for a time $t$ until the indenter ceases to penetrate further.

The tests were carried out using a Rockwell 574 device (Wilson Instruments). The hardness of the wood on transverse, radial and tangential sections was determined for each sample, with one indentation made on each surface using a carbide ball with diameter $D=10 \mathrm{~mm}$. The initial load on the indenting ball was $100 \mathrm{~N}$, and this was increased to a maximum value of $1000 \mathrm{~N}$ over a time of $15 \mathrm{~s}$. The sample was subjected to the maximum load for $30 \mathrm{~s}$, and then over a further $15 \mathrm{~s}$ the load was reduced to its initial value. The total time of one measurement was approximately $1 \mathrm{~min}$. The moisture content of the wood at the time of testing was approximately $12 \%$.

In the next step, measurements were made of two diameters (maximum and minimum) of the indentation made by the ball $(d)$ with an accuracy of $0.01 \mathrm{~mm}$, using a VHX digital microscope (Keyence). The measurements on the radial and tangential sections were particularly difficult, and these required many hours of observation with a magnifying glass and microscope, in addition to preliminary measurements. In total, 14,331 ball indentations were measured, giving 28,662 diameter values.

\subsection{Statistical Analysis}

In view of the wide scope of the analyses and the large number of samples tested, it was necessary to select appropriate statistical methods that would enable reliable evaluation of trends in the properties of birch wood representing different study objects [29-31].

The results were subjected to statistical analysis to determine the impact of location, tree age, tree thickness class and forest habitat type on the mean wood hardness values. Two-way analysis of variance was used for this purpose. The significance of differences in mean values was analysed by means of Tukey's range test and expressed in terms of HSD (honestly significant difference) values computed for a confidence level of $95 \%$. The Statistica 13.3 software was used for statistical analysis [32].

\section{Results}

\subsection{Hardness on a Transverse Section}

Characteristics for the Brinell hardness of silver birch wood on a transverse section depending on location, tree age and forest habitat type are given in Table A1.

Taking account of tree age, the lowest mean hardness value (59.38 MPa) was obtained for 30 year old trees in Rudziniec forest district (FBF), and the highest (72.05 MPa) for 50 year old birches in Giżycko (FMBF), a difference of $21.34 \%$. Depending on location, the lowest mean hardness for silver birch wood $(63.11 \mathrm{MPa})$ was obtained in Bobolice forest district (FBF), and the highest (70.51 MPa) in Giżycko (FMBF), a difference of $11.72 \%$.

For the entire data set, the mean hardness values for the two habitat types differed insignificantly (66.0 MPa for FBF and 66.08 MPa for FMBF). However, an increase in wood hardness was observed with increasing tree age $(64.63,66.05$ and $68.05 \mathrm{MPa}$ respectively for ages of 30, 50 and 70 years).

For the whole of the tested material from all parts of Poland, the mean Brinell hardness of silver birch wood was $66.26 \mathrm{MPa}$. The lowest measured hardness for a single sample was $45.47 \mathrm{MPa}$ for a 30 year old tree (FBF habitat type), and the highest was $95.92 \mathrm{MPa}$ for a 50 year old tree (FBF habitat type).

It was shown that the location of study plots and the age of trees, and the interaction between these factors, generate statistically significant differences in mean hardness values between the analysed groups. The effect of the analysed factors on the wood hardness values was not large, as indicated by the eta-square $\left(\eta^{2}\right)$ values. A summary of the results is given in Table 1 . 
Table 1. Effect of location and tree age and the interaction of these factors on wood hardness (two-way analysis of variance).

\begin{tabular}{|c|c|c|c|c|c|c|}
\hline $\begin{array}{l}\text { Source of } \\
\text { Variance }\end{array}$ & $\begin{array}{l}\text { Sum of } \\
\text { Squares }\end{array}$ & $\begin{array}{c}\text { Degrees of } \\
\text { Freedom }\end{array}$ & $\begin{array}{c}\text { Mean } \\
\text { Squares }\end{array}$ & F Empirical & Eta-Square $\left(\eta^{2}\right)$ Values & $p$-Value \\
\hline Intercept & $20,811,460$ & 1 & $20,811,460$ & $533,684.3$ & 0.9912 & $<0.0001$ * \\
\hline Location & 21,228 & 16 & 1327 & 34.0 & 0.1033 & $<0.0001$ * \\
\hline Age & 9556 & 2 & 4778 & 122.5 & 0.0493 & $<0.0001$ * \\
\hline $\begin{array}{c}\text { Location-Age } \\
\text { (interaction) }\end{array}$ & 21,941 & 32 & 686 & 17.6 & 0.1064 & $<0.0001 *$ \\
\hline Error & 184,294 & 4726 & 39 & & & \\
\hline
\end{tabular}

Table 2 contains groups of locations that do not differ statistically significantly in terms of mean values of wood hardness. The forest districts of Bobolice (FBF) and Rudziniec (FBF) have the lowest hardness. The highest mean hardness values were obtained for the districts of Giżycko (FMBF) and Sokołów (FBF); the difference between these values was not significant.

Table 2. Homogeneous groups of locations in terms of mean wood hardness (HSD Tukey's range test).

\begin{tabular}{ccccccccc}
\hline Location & Mean & $\mathbf{1}$ & $\mathbf{2}$ & $\mathbf{3}$ & $\mathbf{4}$ & $\mathbf{5}$ & $\mathbf{6}$ & $\mathbf{7}$ \\
\hline Bobolice FBF & 63.11 & $* * * *$ & & & & & & \\
Rudziniec FBF & 63.84 & $* * * *$ & $* * * *$ & & & & & \\
Górowo Iławeckie FBF & 64.08 & $* * * *$ & $* * * *$ & & & & & \\
Łobez FMBF & 64.12 & $* * * *$ & $* * * *$ & & & & & \\
Płońsk FBF & 64.63 & $* * * *$ & $* * * *$ & $* * * *$ & & & & \\
Bobolice FMBF & 64.64 & $* * * *$ & $* * * *$ & $* * * *$ & & & & \\
Elblag FBF & 65.01 & $* * * *$ & $* * * *$ & $* * * *$ & & & & \\
Płaska FBF & 65.33 & & $* * * *$ & $* * * *$ & $* * * *$ & & & \\
Lipinki FBF & 66.14 & & & $* * * *$ & $* * * *$ & $* * * *$ & & \\
Rudziniec FMBF & 67.07 & & & & $* * * *$ & $* * * *$ & & \\
Biała Podlaska FBF & 67.20 & & & & $* * * *$ & $* * * *$ & & \\
Łobez FBF & 67.27 & & & & $* * * *$ & $* * * *$ & & \\
Lipinki FMBF & 67.50 & & & & & $* * * *$ & & \\
Mircze FBF & 67.93 & & & & & $* * * *$ & & \\
Giżycko FBF & 68.05 & & & & & $* * * *$ & $* * * *$ & $*$ \\
Sokołów FBF & 70.14 & & & & & & $* * * *$ & $* * * *$ \\
Giżycko FMBF & 70.51 & & & & & & & $* * * *$ \\
\hline
\end{tabular}

The differences in wood hardness values in the analysed age classes were not large; however, because of the large number of observations, they were statistically significant. The mean hardness values increase with age (Figure 2).

Analysis of the dependence of wood hardness on stand location and age indicated the existence of homogeneous groups in a very complex system, for which it is hard to identify any general trend (Figure 3). In the forest districts of Giżycko (FBF), Górowo Iławeckie, Elblag and Bobolice (FBF and FMBF), Łobez (FBF and FMBF), Lipinki (FBF and FMBF) and Rudziniec (FBF), the highest mean hardness was recorded for the oldest trees (70 years). The greatest hardness was recorded for 50 year old trees in Giżycko (FMBF) and for 30 year old trees in Płońsk, Sokołów, Płaska, Mircze and Rudziniec (FMBF). In the Płaska and Mircze districts the hardness was almost identical for all ages. At eight locations the lowest hardness was obtained for wood from 30 year old trees. 


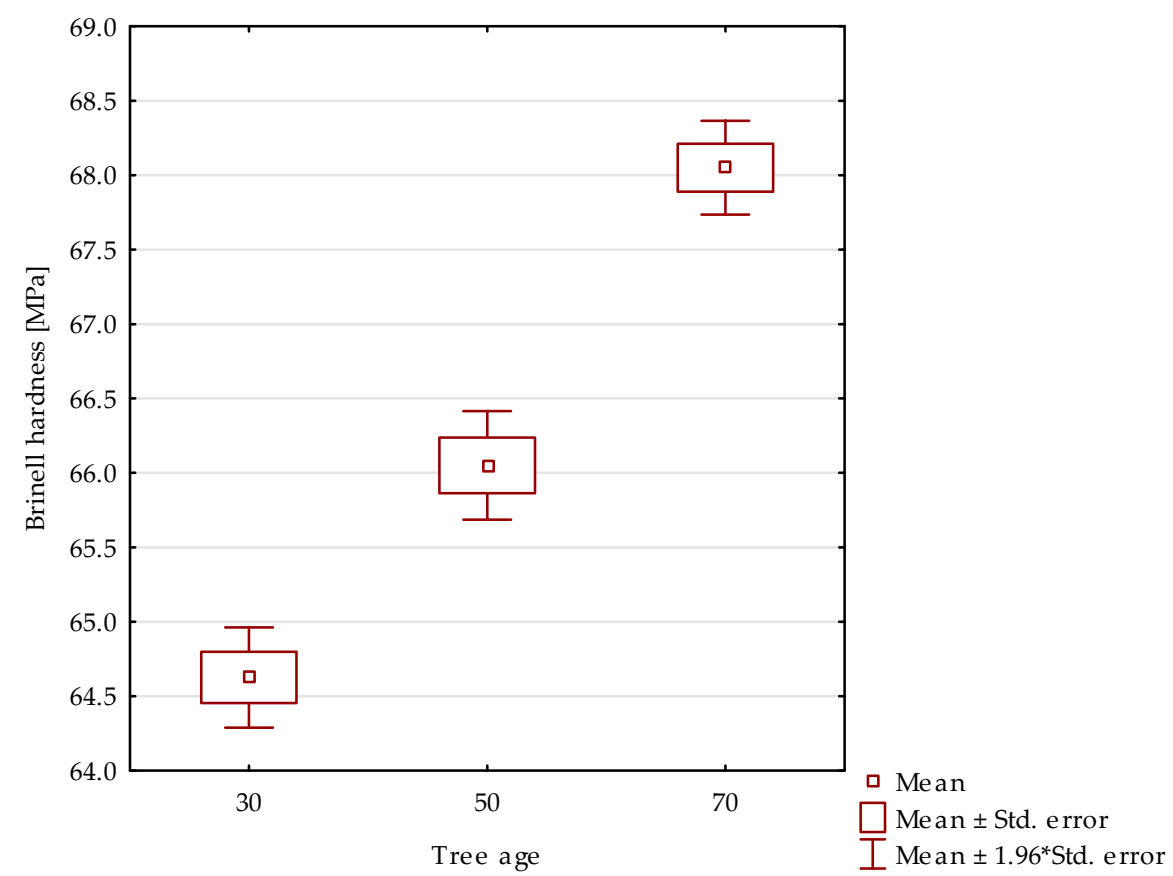

Figure 2. Mean values of wood hardness for trees of different ages.

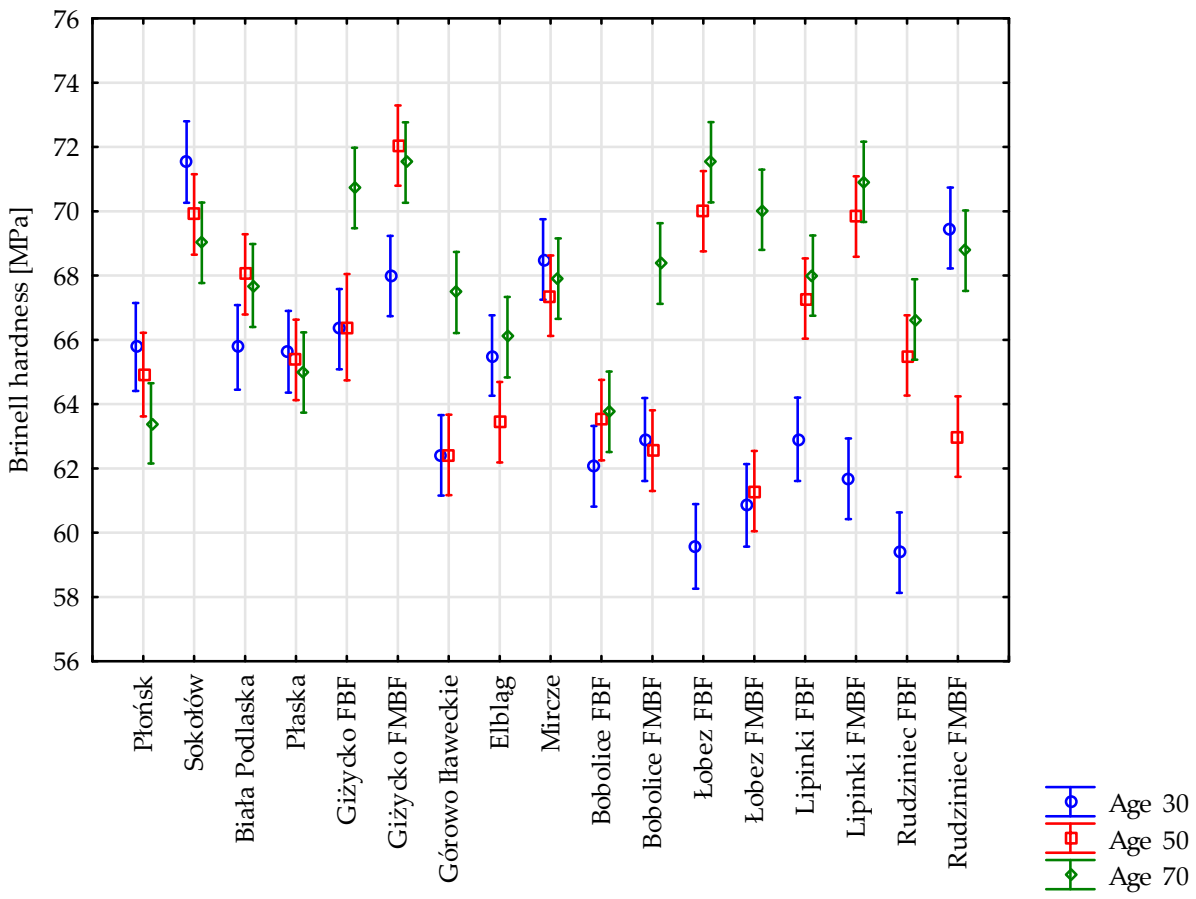

Figure 3. Mean wood hardness values and standard errors, for location and age.

The significance of differences in mean wood hardness values was also examined for groups defined by tree age and thickness. The effect of both factors and their interaction on wood hardness was found to be very small (as indicated by eta-square values), but statistically significant (Table 3). Only in the case of the oldest trees was no relationship identified between tree thickness and wood hardness. The hardness was found to increase with increasing age of the stand from which the study material originated (Table 4). For all ages, the highest mean wood hardness was recorded for the thinnest trees. In 30 year old trees the hardness decreased with increasing tree thickness, whereas in 50 year old birches the lowest mean hardness was recorded for trees of moderate thickness. 
Table 3. Effect on wood hardness of tree age and thickness class and interaction between these factors (two-way analysis of variance).

\begin{tabular}{ccccccc}
\hline $\begin{array}{c}\text { Source of } \\
\text { Variance }\end{array}$ & $\begin{array}{c}\text { Sum of } \\
\text { Squares }\end{array}$ & $\begin{array}{c}\text { Degrees of } \\
\text { Freedom }\end{array}$ & Mean Squares & F Empirical & Eta-Square $\left(\eta^{2}\right)$ Values & $p$-Value \\
\hline $\begin{array}{c}\text { Intercept } \\
\text { Age }\end{array}$ & $20,950,025$ & 1 & $20,950,025$ & $450,142.7$ & 0.9895 & $<0.0001^{*}$ \\
$\begin{array}{c}\text { Thickness class } \\
\text { Age-Thickness }\end{array}$ & 9112 & 2 & 4556 & 97.9 & 0.0394 & $<0.0001^{*}$ \\
$\begin{array}{c}\text { class } \\
\text { (interaction) }\end{array}$ & 3263 & 2 & 1631 & 15.1 & 0.0125 \\
Error & 2801 & 4 & 700 & & $<0.0001^{*}$ \\
\hline
\end{tabular}

* statistically significant at the 0.05 level.

Table 4. Homogeneous groups in terms of mean wood hardness values for tree age and thickness class (HSD Tukey's range test).

\begin{tabular}{cccccccc}
\hline Age & Thickness Class & Mean & $\mathbf{1}$ & $\mathbf{2}$ & $\mathbf{3}$ & $\mathbf{4}$ & $\mathbf{5}$ \\
\hline 30 & 3 & 62.88 & & & & & $* * * * *$ \\
50 & 2 & 64.49 & & & $* * * *$ & & \\
30 & 2 & 64.65 & & & $* * * *$ & & \\
50 & 3 & 66.16 & & & & $* * * *$ & \\
30 & 1 & 66.56 & & $* * * *$ & & $* * * *$ & \\
50 & 1 & 67.49 & $* * * *$ & $* * * *$ & & & \\
70 & 2 & 67.66 & $* * * *$ & $* * * *$ & & & \\
70 & 3 & 68.23 & $* * * *$ & & & & \\
70 & 1 & 68.27 & $* * * *$ & & & & \\
\hline
\end{tabular}

For the forest districts where birch trees from both FBF and FMBF habitat types were studied, an analysis was undertaken of the dependence of wood hardness on the location of the study plots and the habitat type. It was shown that both factors, and the interaction between them, generate statistically significant differences in the mean hardness values between the analysed groups, although the $\eta^{2}$ values indicate that these factors have a very weak impact on the wood hardness values (Table 5).

Table 5. Effect on wood hardness of location and habitat type and interaction between these factors (two-way analysis of variance).

\begin{tabular}{ccccccc}
\hline $\begin{array}{c}\text { Source of } \\
\text { Variance }\end{array}$ & $\begin{array}{c}\text { Sum of } \\
\text { Squares }\end{array}$ & $\begin{array}{c}\text { Degrees of } \\
\text { Freedom }\end{array}$ & Mean Squares & F Empirical & Eta-Square $\left(\eta^{2}\right)$ Values & $p$-Value \\
\hline $\begin{array}{c}\text { Intercept } \\
\text { Location }\end{array}$ & $12,288,009$ & 1 & $12,288,009$ & $268,156.4$ & 0.9897 & $<0.0001^{*}$ \\
$\begin{array}{c}\text { Forest habitat } \\
\text { type (FHT) }\end{array}$ & 8792 & 4 & 2198 & 48.0 & 0.0642 & 0.0064 \\
$\begin{array}{c}\text { Location-FHT } \\
\text { (interaction) }\end{array}$ & 823 & 1 & 823 & 18.0 & $0.0001^{*}$ \\
Error & 128,170 & 4 & 869 & 19.0 & $<0.0001^{*}$ \\
\hline
\end{tabular}

* statistically significant at the 0.05 level.

The results of grouping the study plot locations taking account of habitat type are given in Table 6. Statistically significant differences in wood hardness between habitat types were identified for the districts of Giżycko, Łobez and Rudziniec. A higher mean hardness was found for samples from trees growing in the FMBF habitat type in the districts of Giżycko, Bobolice, Lipinki and Rudziniec (the hardness was lower in the more fertile FBF habitat type). In the Łobez district the pattern was reversed: the mean hardness rose with an increase in habitat fertility from FMBF to FBF. 
Table 6. Homogeneous groups in terms of mean wood hardness values for locations and habitat types (HSD Tukey's range test).

\begin{tabular}{ccccccc}
\hline Location & FHT & Mean & $\mathbf{1}$ & $\mathbf{2}$ & $\mathbf{3}$ & $\mathbf{4}$ \\
\hline Bobolice & FBF & 63.11 & & $* * * *$ & & \\
Rudziniec & FBF & 63.84 & & $* * * *$ & & \\
Łobez & FMBF & 64.12 & & $* * * *$ & $* * * *$ & \\
Bobolice & FMBF & 64.64 & & $* * * *$ & \\
Lipinki & FBF & 66.14 & $* * *$ & & \\
Rudziniec & FMBF & 67.07 & $* * * *$ & & \\
Łobez & FBF & 67.27 & $* * * *$ & & \\
Lipinki & FMBF & 67.50 & $* * * *$ & & \\
Giżycko & FBF & 68.05 & $* * * *$ & & \\
Giżycko & FMBF & 70.51 & & & & \\
\hline
\end{tabular}

\subsection{Hardness on a Radial Section}

The effect of the analysed factors on the Brinell hardness was found to be practically identical for the radial and tangential sections of silver birch wood. For this reason, analysis is presented here only for the results obtained on a radial section.

Characteristics for the Brinell hardness of silver birch wood on a radial section depending on location, tree age and habitat type are given in Table A2.

Analysing the results for the dependence of birch wood hardness on tree age, it was found that the lowest mean hardness $(38.70 \mathrm{MPa})$ was obtained for 30 year old birches in Łobez district (FBF), and the highest (50.52 MPa) for 30 year old trees in Sokołów (FBF), a difference of $30.54 \%$. The results for locations show that the lowest mean hardness was obtained for wood in Bobolice district (FBF) (40.58 MPa), and the highest in Sokołów (FBF) (49.71 MPa), a $22.50 \%$ difference.

Mean hardness values for the whole of the studied material were respectively 44.6 and 42.7 MPa for habitat types FBF and FMBF. There was also found to be a slight increase in wood hardness with increasing tree age: $43.3 \mathrm{MPa}$ for 30 year old trees, $44.1 \mathrm{MPa}$ for 50 year old trees, and $44.8 \mathrm{MPa}$ for 70 year old trees.

The mean Brinell hardness of Polish birch wood obtained for the whole of the analysed material was $44.06 \mathrm{MPa}$. The lowest hardness of a single sample was $30.97 \mathrm{MPa}$ for a 30 year old tree (FBF habitat type), and the highest was $63.65 \mathrm{MPa}$ for a 70 year old tree (FBF habitat type).

It was shown that study plot location and tree age, and the interaction between these factors, generate statistically significant differences in mean wood hardness between the analysed groups. The effect of these factors on the hardness values is not large, as indicated by the eta-square $\left(\eta^{2}\right)$ values. A summary of the results is given in Table 7 .

Table 7. Effect on wood hardness of location and tree age and the interaction of these factors (two-way analysis of variance).

\begin{tabular}{|c|c|c|c|c|c|c|}
\hline $\begin{array}{l}\text { Source of } \\
\text { Variance }\end{array}$ & $\begin{array}{l}\text { Sum of } \\
\text { Squares }\end{array}$ & $\begin{array}{l}\text { Degrees of } \\
\text { Freedom }\end{array}$ & Mean Squares & F Empirical & Eta-Square $\left(\eta^{2}\right)$ Values & $p$-Value \\
\hline Intercept & $9,226,766$ & 1 & $9,226,766$ & 881.275 .1 & 0.9947 & $<0.0001$ * \\
\hline Location & 41,329 & 16 & 2583 & 246.7 & 0.4551 & $<0.0001$ * \\
\hline Age & 1836 & 2 & 918 & 87.7 & 0.0358 & $<0.0001$ * \\
\hline $\begin{array}{l}\text { Location-Age } \\
\text { (interaction) }\end{array}$ & 3996 & 32 & 125 & 11.9 & 0.0747 & $<0.0001 *$ \\
\hline Error & 49,480 & 4726 & 10 & & & \\
\hline
\end{tabular}

The columns of Table 8 contain groups of locations that do not differ statistically significantly in terms of mean wood hardness. The lowest hardness values were obtained for Bobolice (FBF), Rudziniec (FBF) and Bobolice (FMBF). The mean wood hardness values 
were highest for trees growing in Sokołów district (FBF); these were statistically significantly different from the remaining values.

Table 8. Homogeneous groups of locations in terms of mean wood hardness (HSD Tukey's range test).

\begin{tabular}{ccccccccccc}
\hline Location & Mean & $\mathbf{1}$ & $\mathbf{2}$ & $\mathbf{3}$ & $\mathbf{4}$ & $\mathbf{5}$ & $\mathbf{6}$ & $\mathbf{7}$ & $\mathbf{8}$ & $\mathbf{9}$ \\
\hline Bobolice FBF & 40.58 & $* * * *$ & & & & & & & \\
Rudziniec FBF & 41.11 & $* * * *$ & $* * * *$ & & & & & & \\
Bobolice FMBF & 41.41 & $* * * *$ & $* * * *$ & & & & & & \\
Lipinki FBF & 41.63 & & $* * * *$ & & & & & & \\
Lipinki FMBF & 41.65 & & $* * * *$ & & & & & & \\
Łobez FMBF & 41.70 & & $* * * *$ & & & & & & \\
Rudziniec FMBF & 41.71 & & $* * * *$ & & & & & & \\
Łobez FBF & 42.00 & & $* * * *$ & $* * * *$ & & & & & \\
Elblag FBF & 42.97 & & & $* * * *$ & $* * * *$ & & & & \\
Mircze FBF & 43.62 & & & & $* * * *$ & $* * * *$ & & & \\
Górowo Iławeckie FBF & 44.49 & & & & & $* * * *$ & & & \\
Płaska FBF & 46.15 & & & & & & $* * * *$ & & & \\
Giżycko FMBF & 47.03 & & & & & & $* * * * *$ & $* * * *$ & & \\
Płońsk FBF & 47.54 & & & & & & & $* * * *$ & $* * * *$ & \\
Biała Podlaska FBF & 48.22 & & & & & & & & $* * * *$ & \\
Giżycko FBF & 48.40 & & & & & & & & $* * * *$ & \\
Sokołów FBF & 49.71 & & & & & & & & & $* * * *$ \\
\hline
\end{tabular}

The differences in wood hardness values for the analysed classes were not large, but because of the large number of observations, they were statistically significant. The mean hardness values increase with age (Figure 4).

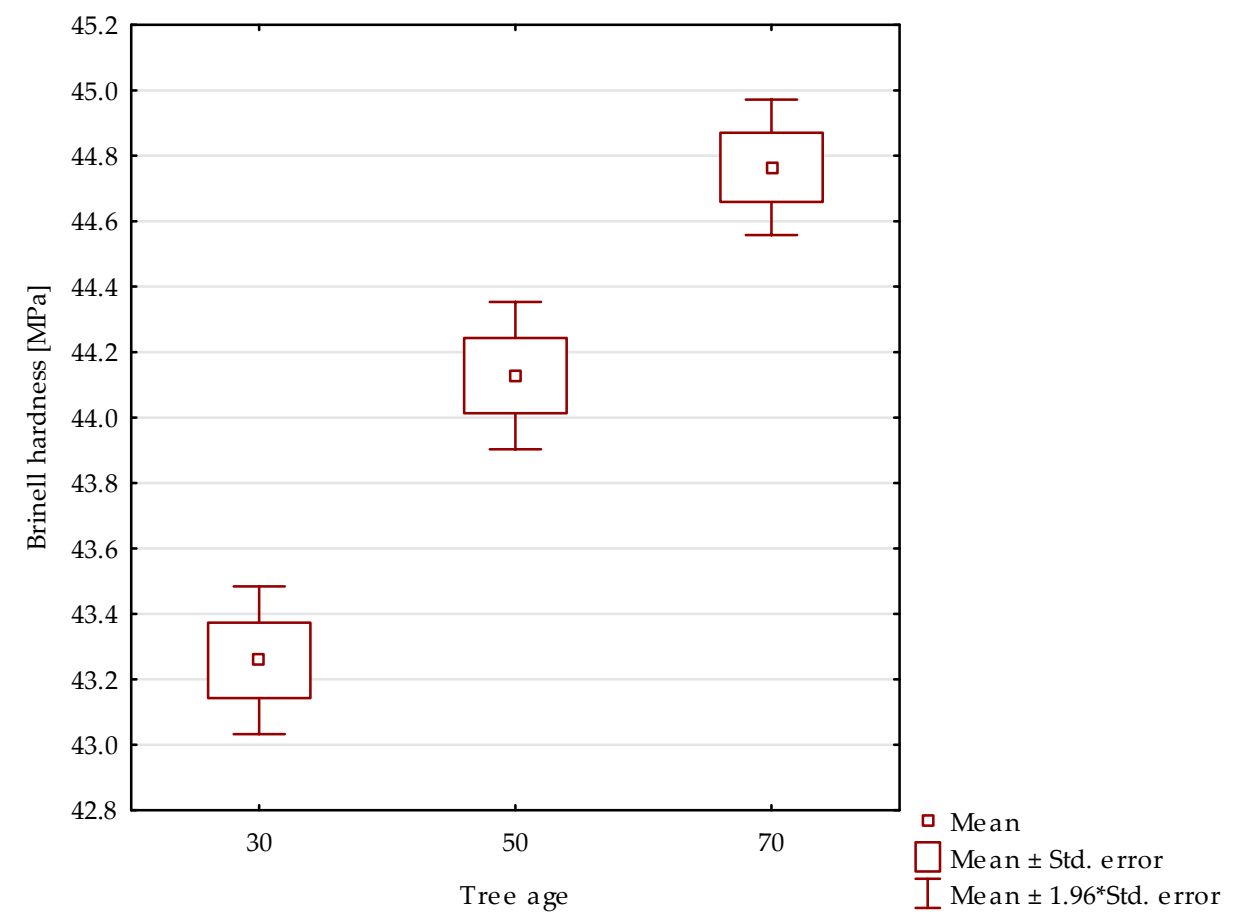

Figure 4. Mean wood hardness values for trees of different ages.

An analysis was also undertaken of the dependence of wood hardness on study plot location and tree age. This showed the existence of homogeneous groups in a very complex system (Figure 5). In the districts of Giżycko (FBF and FMBF), Górowo Iławeckie, Mircze, Bobolice (FBF and FMBF), Łobez (FMBF), Lipinki (FMBF) and Rudziniec (FMBF), the highest mean hardness was obtained for the oldest trees (70 years). The highest values 
were obtained for 50 year old trees in the districts of Płońsk, Łobez (FBF), Lipinki (FBF) and Rudziniec (FBF), and for 30 year old trees in Sokołów and Płaska. In Elblag the wood hardness was almost identical for all ages. At 10 locations the lowest hardness was recorded for 30 year old trees. In general, the mean hardness values for birch wood of all ages were higher in the eastern part of Poland.

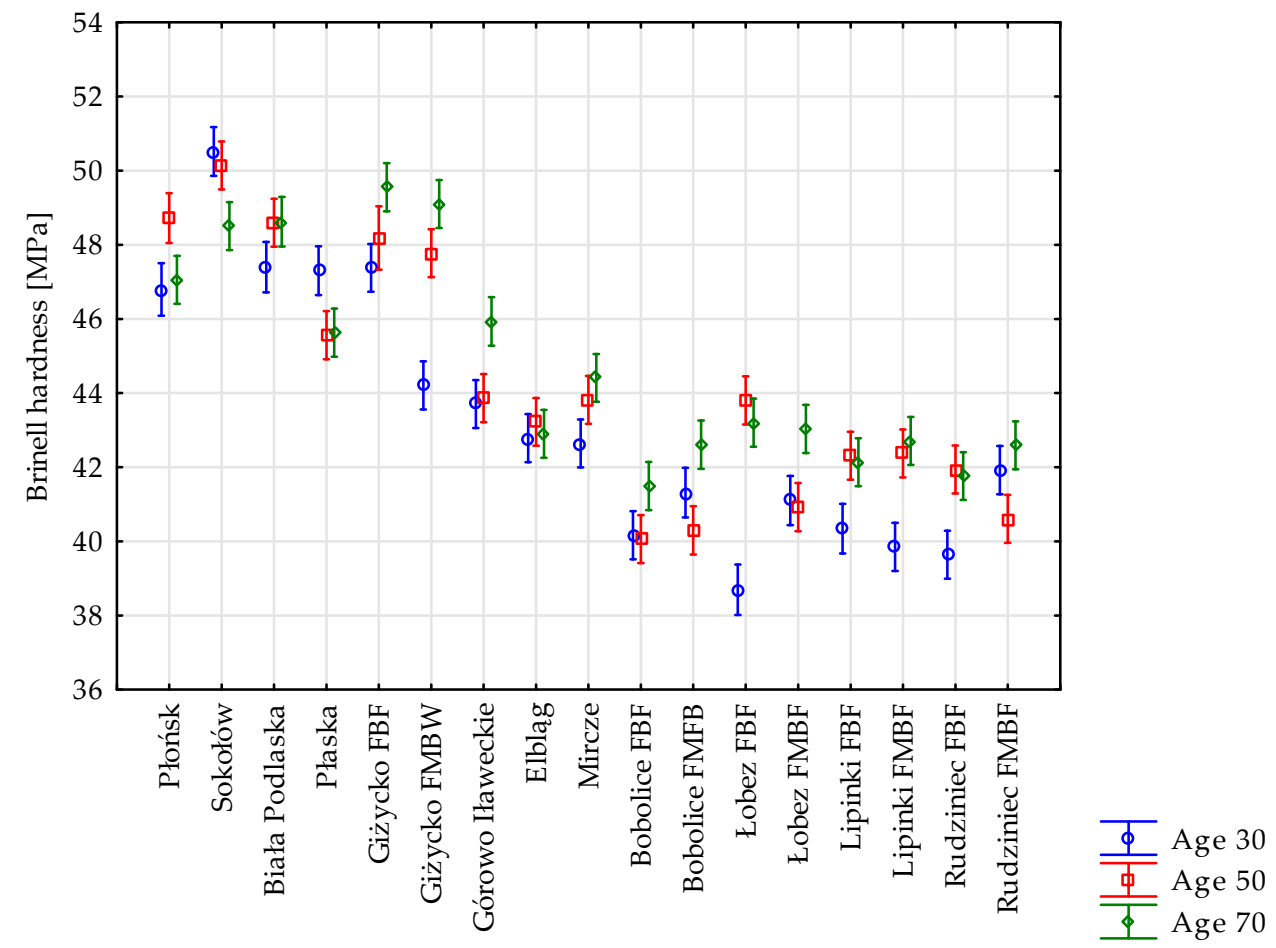

Figure 5. Mean wood hardness values and standard errors, for location and age.

An analysis was undertaken of the significance of the differences in mean hardness values between groups defined based on the age and thickness of trees. It was found that the effect of both of these factors, and their interaction, on wood hardness was very small (as indicated by eta-square values), but was statistically significant (although the significance of the interaction was close to the boundary value of 0.05) (Table 9). Within observations representing the same age class, no relationship was found between the tree thickness class and the wood hardness. With an increase in the age of the stand from which the study material originated, the wood hardness was found to increase (Table 10). For wood of all ages, the lowest mean hardness was found for trees of moderate thickness.

Table 9. Effect on wood hardness of tree age and thickness class and the interaction of these factors (two-way analysis of variance).

\begin{tabular}{|c|c|c|c|c|c|c|}
\hline $\begin{array}{l}\text { Source of } \\
\text { Variance }\end{array}$ & $\begin{array}{l}\text { Sum of } \\
\text { Squares }\end{array}$ & $\begin{array}{c}\text { Degrees of } \\
\text { Freedom }\end{array}$ & Mean Squares & F Empirical & Eta-Square $\left(\eta^{2}\right)$ Values & $p$-Value \\
\hline Intercept & $9,259,580$ & 1 & $9,259,580$ & $467,110.4$ & 0.9899 & $<0.0001$ * \\
\hline Age & 1787 & 2 & 893 & 45.1 & 0.0186 & $<0.0001$ * \\
\hline Thickness class & 341 & 2 & 170 & 8.6 & 0.0036 & $0.0002 *$ \\
\hline $\begin{array}{c}\text { Age-Thickness } \\
\text { class } \\
\text { (interaction) }\end{array}$ & 195 & 4 & 49 & 2.5 & 0.0021 & $0.0433 *$ \\
\hline Error & 94,517 & 4768 & 20 & & & \\
\hline
\end{tabular}


Table 10. Homogeneous groups in terms of mean wood hardness values for tree age and thickness class (HSD Tukey's range test).

\begin{tabular}{cccccccc}
\hline Age & Thickness Class & Mean & $\mathbf{1}$ & $\mathbf{2}$ & $\mathbf{3}$ & $\mathbf{4}$ & $\mathbf{5}$ \\
\hline 30 & 2 & 42.93 & $* * * *$ & & & & \\
30 & 3 & 43.24 & $* * * *$ & $* * * *$ & & & \\
50 & 2 & 43.64 & $* * * *$ & $* * * *$ & $* * * *$ & & \\
30 & 1 & 43.65 & $* * * *$ & $* * * *$ & $* * * *$ & & \\
50 & 1 & 44.00 & & $* * * *$ & $* * * *$ & & $* * * *$ \\
70 & 2 & 44.48 & & & $* * * *$ & $* * * *$ & $* * * *$ \\
50 & 3 & 44.74 & & & & $* * * *$ & $* * * *$ \\
70 & 3 & 44.91 & & & & $* * * *$ & \\
70 & 1 & 44.91 & & & & $* * * *$ & \\
\hline
\end{tabular}

For the districts where the properties of birch wood from habitat types FBF and FMBF were investigated, an analysis was made of the dependence of the wood hardness on the location of the study plot and the habitat type. Statistically significant differences in mean hardness values were found between groups defined on the basis of study plot location and as a result of interaction between location and habitat type, although the values of $\eta^{2}$ indicate that these factors had a very weak effect on the hardness. The effect of habitat on wood hardness at the analysed locations (except for Giżycko) was statistically insignificant (Table 11).

Table 11. Effect on wood hardness of location and habitat type and the interaction between these factors (two-way analysis of variance).

\begin{tabular}{ccccccc}
\hline $\begin{array}{c}\text { Source of } \\
\text { Variance }\end{array}$ & $\begin{array}{c}\text { Sum of } \\
\text { Squares }\end{array}$ & $\begin{array}{c}\text { Degrees of } \\
\text { Freedom }\end{array}$ & Mean Squares & F Empirical & Eta-Square $\left(\eta^{2}\right)$ Values & $p$-Value \\
\hline Intercept & $5,113,265$ & 1 & $5,113,265$ & 465,364 & 0.994 & $<0.0001^{*}$ \\
Location & 17,027 & 4 & 4257 & 387.4 & 0.3565 & $0.0001^{*}$ \\
FHT & 2 & 1 & 2 & 0.1 & 0.0133 & $<0.00011^{*}$ \\
$\begin{array}{c}\text { Location-FHT } \\
\text { (interaction) }\end{array}$ & 414 & 4 & 103 & 9.4 & \\
Error & 30,733 & 2797 & 11 & & \\
\hline
\end{tabular}

${ }^{*}$ statistically significant at the 0.05 level.

The results of grouping the study plot locations taking account of the habitat type are given in Table 12. This set of results show that only the observations from Giżycko forest district differ significantly from those of the other locations.

Table 12. Homogeneous groups in terms of mean wood hardness values for locations and habitat types (HSD Tukey's range test).

\begin{tabular}{cccccccc}
\hline Location & FHT & Mean & $\mathbf{1}$ & $\mathbf{2}$ & $\mathbf{3}$ & $\mathbf{4}$ & $\mathbf{5}$ \\
\hline Bobolice & FBF & 40.58 & & & $* * * *$ & & \\
Rudziniec & FBF & 41.11 & $* * * *$ & & $* * * *$ & & \\
Bobolice & FMBF & 41.41 & $* * * *$ & $* * * *$ & $* * * *$ & & \\
Lipinki & FBF & 41.63 & $* * * *$ & $* * * *$ & & \\
Lipinki & FMBF & 41.65 & $* * * *$ & $* * * *$ & & \\
Łobez & FMBF & 41.70 & $* * * *$ & $* * * *$ & & \\
Rudziniec & FMBF & 41.71 & $* * * *$ & $* * * *$ & & & \\
Łobez & FBF & 42.00 & & $* * * *$ & & $* * * *$ & \\
Giżycko & FMBF & 47.03 & & & & & $* * * *$ \\
Giżycko & FBF & 48.40 & & & & & \\
\hline
\end{tabular}




\section{Discussion}

The analysis of raw material sources in terms of the properties determining technical quality is fundamental to the continued use of wood. Hardness is one of the parameters that determine wood quality. Because of the non-uniform structure of wood, it is necessary to make a distinction between analysed surfaces. In general, the hardness of wood on a transverse section is 1.5 to 2 times higher than on the longitudinal sections [1]. In the present study the hardness on the transverse section was found to be 1.5 times higher on average than the hardness on the longitudinal sections. On Mörath's six-point scale, which is based on Brinell hardness, birch — together with alder, sycamore, lime, pine, larch and Douglas fir-is placed in class II, as a soft wood with hardness between 35.30 and $48.05 \mathrm{MPa}$ [6]. Following the testing of 4777 samples from 51 study plots, based on the hardness on the transverse section, the silver birch wood from 16 of the plots can be classified as hard (hardness class IV, $58.84-63.74 \mathrm{MPa}$ ), and that from 35 plots as very hard (class V, 64.72-143.18 MPa). In the northeast of the country, the wood was classed as very hard in the large majority of cases. The wood was placed in the hard category in only four of the 16 plots studied in that part of Poland.

Of the studied locations, in 11 cases the mean hardness values enable the birch wood to be classified as very hard, namely Elblag, Płaska, Lipinki (FBF), Rudziniec (FMBF), Biała Podlaska, Łobez (FBF), Lipinki (FMBF), Mircze, Giżycko (FBF), Sokołów and Giżycko (FMBF).

Based on the hardness values on a radial section, in a large majority of cases (47 plots) the silver birch wood is classified as soft on Mörath's scale (hardness class II, 35.30-48.05 MPa). There were only four plots (in the east of Poland) where the wood could be classified as moderately hard (class III, 49.03-57.86 MPa).

Considering mean hardness values for location, only the wood from Sokołów district was determined to be moderately hard; the wood from the other locations was classed as soft.

The values obtained in this study are significantly higher than others reported in the literature. Wagenführ [33] gives Brinell hardness values for birch between 22.00 and 49.00 MPa, which are lower than the values measured in this study. Similarly, Schwab [34] obtained values for the hardness of birch wood in the range 13.0-32.8 MPa, although these concerned finished strips used for the production of panels. Heräjärvi [35] obtained mean hardness values on a transverse section of 23.40 MPa for silver birch and 20.50 MPa for downy birch. Möttönen et al. [18] showed, in a study of birch trees aged 27-35 years, that the Brinell hardness of the wood was also affected by the season in which the wood was obtained (the highest value, $21.75 \mathrm{MPa}$, was recorded in winter); the drying method (the highest value, $21.10 \mathrm{MPa}$, was obtained when a vacuum dryer was used); and distance from the core (the highest value, $25.36 \mathrm{MPa}$, was recorded at a distance of 10-12 cm from the core). All of these values are lower than those obtained in the present study. Mania et al. [17] obtained a mean value of $34 \mathrm{MPa}$ for the Brinell hardness of birch wood on a tangential section; this value increased to $90 \mathrm{MPa}$ following compaction of the wood, and to as much as $147 \mathrm{MPa}$ following compaction preceded by chemical treatment. Laskowska [13] obtained a mean value of $31 \mathrm{MPa}$ on a tangential section, noting that, depending on the time and temperature of compaction, the hardness of birch wood can be increased between 1.4 and 2.2 times.

Schwab [34] reported that the Brinell hardness may be calculated mathematically from hardness values obtained by Janka's method. In addition, Bektas et al. [36] demonstrated a linear relationship between Janka and Brinell hardness, in the case of beech wood. However, Kozakiewicz et al. [2] indicated that Brinell and Janka hardness values should not be compared.

In contrast to Krzysik [6], Heräjärvi [35] and Möttönen et al. [18], who report a clear relationship between wood density and hardness, the present study indicates that wood of higher density is not always harder. Tests on the same set of samples indicate that the values of these parameters are not always in correspondence. Birch wood from Płońsk, 
in spite of its high density, does not attain a proportionally high hardness measured on a transverse section [23]. The hardness of wood from that location is high on longitudinal sections. It has been shown that higher values of hardness on a transverse section do not always correspond to higher values on longitudinal sections. Mean hardness values for particular tree ages exhibit less variability on radial than on transverse sections.

On transverse sections, the higher the wood hardness, the rounder the indentation made by the ball. On longitudinal sections, the indentations were elliptical in shape, with a longer axis along the fibres. This affects the accuracy of the measurement. The diameter of the indentation is most easily and accurately measured on the transverse section, followed by the tangential. Measurement is by far the most difficult on the radial section, because of the presence of rays that strongly reflect the light of the microscope lamp.

\section{Conclusions}

1. There was found to be a significant effect from location, tree age, tree thickness and habitat type, and from the interactions between these factors, on the Brinell hardness of Polish silver birch wood measured both on transverse sections and on longitudinal radial sections. Habitat type was not shown to influence the radial hardness except in the case of Giżycko forest district.

2. For the whole of the analysed material, the mean hardness on a transverse section was $66.26 \mathrm{MPa}$, which indicates that the birch wood is very hard on Mörath's scale, whereas the values on the longitudinal sections (radial 44.06 MPa, tangential 44.02 $\mathrm{MPa}$ ) indicate it to be a soft wood.

3. For the whole of the analysed material, the ratio of the wood hardness on a transverse section to the mean hardness on the longitudinal sections was 1.5.

4. The highest mean values of hardness on a transverse section were recorded for wood from the forest districts of Giżycko (FMBF) (70.51 MPa) and Sokołów (FBF) (70.14 MPa), and the highest mean values on a radial section were recorded for Sokołów (FBF) (49.71 MPa) and Giżycko (FBF) (48.40 MPa).

5. For the whole of the analysed material, on both transverse and radial sections, the mean values of wood hardness increased with tree age.

6. In birch stands in all parts of Poland, trees with very high and low wood hardness grow alongside each other, irrespective of geographical location, tree age and thickness, and habitat type.

Author Contributions: Conceptualization, H.L.; methodology, H.L., A.S., J.L.-B. and A.K.; software, R.W., J.L.-B., A.K. and A.K.G.; formal analysis, H.L., R.W. and A.K.G.; investigation, H.L. and A.K.G.; resources, H.L. and A.K.G.; writing-original draft preparation, H.L., R.W. and A.K.G.; writingreview and editing, H.L. and A.K.G.; visualization, R.W. and A.K.G.; supervision, H.L.; project administration, H.L.; funding acquisition, H.L. All authors have read and agreed to the published version of the manuscript.

Funding: This work was supported by the General Directorate of the State Forests in Poland (grant number EO-2717-13/13). Hardness tests were carried out during a research project financed from the Scholarship Fund awarded by the Rector of Warsaw University of Life Sciences.

Data Availability Statement: The data presented in this study are available on request from the first author.

Conflicts of Interest: The authors declare no conflict of interest. The funders had no role in the design of the study; in the collection, analyses, or interpretation of data; in the writing of the manuscript, or in the decision to publish the results. 


\section{Appendix A}

Table A1. Characteristics of Brinell hardness of silver birch wood on a transverse section (MPa).

\begin{tabular}{|c|c|c|c|c|c|c|c|}
\hline $\begin{array}{l}\text { Location- } \\
\text { Forest District }\end{array}$ & Tree Age & $\begin{array}{l}\text { Number of } \\
\text { Groups (N) }\end{array}$ & Mean & Median & Minimum & Maximum & $\begin{array}{l}\text { Standard } \\
\text { Deviation }\end{array}$ \\
\hline \multirow{4}{*}{$\begin{array}{c}1 \\
\text { Płońsk } \\
\text { FBF }\end{array}$} & 30 & 80 & 65.78 & 65.84 & 56.45 & 75.65 & 4.26 \\
\hline & 50 & 89 & 64.92 & 63.47 & 54.59 & 83.24 & 6.05 \\
\hline & 70 & 96 & 63.40 & 63.77 & 55.32 & 74.33 & 3.45 \\
\hline & Total & 265 & 64.63 & 64.22 & 54.59 & 83.24 & 4.78 \\
\hline \multirow{4}{*}{$\begin{array}{c}2 \\
\text { Sokołów } \\
\text { FBF }\end{array}$} & 30 & 93 & 71.53 & 71.60 & 57.47 & 86.63 & 6.24 \\
\hline & 50 & 96 & 69.90 & 69.86 & 55.94 & 85.48 & 6.48 \\
\hline & 70 & 96 & 69.02 & 68.84 & 56.19 & 89.73 & 6.70 \\
\hline & Total & 285 & 70.14 & 70.20 & 55.94 & 89.73 & 6.54 \\
\hline \multirow{4}{*}{$\begin{array}{c}3 \\
\text { Biała Podlaska } \\
\text { FBF }\end{array}$} & 30 & 87 & 65.76 & 65.19 & 53.68 & 81.16 & 5.98 \\
\hline & 50 & 96 & 68.04 & 67.19 & 55.14 & 87.74 & 7.88 \\
\hline & 70 & 90 & 67.69 & 66.92 & 57.72 & 82.31 & 5.54 \\
\hline & Total & 273 & 67.20 & 66.30 & 53.68 & 87.74 & 6.63 \\
\hline \multirow{4}{*}{$\begin{array}{c}4 \\
\text { Płaska } \\
\text { FBF }\end{array}$} & 30 & 93 & 65.63 & 64.58 & 56.24 & 85.79 & 6.30 \\
\hline & 50 & 96 & 65.38 & 60.92 & 52.34 & 89.15 & 10.22 \\
\hline & 70 & 96 & 64.98 & 63.20 & 51.08 & 85.79 & 7.68 \\
\hline & Total & 285 & 65.33 & 63.20 & 51.08 & 89.15 & 8.22 \\
\hline \multirow{4}{*}{$\begin{array}{c}5 \\
\text { Giżycko } \\
\text { FBF }\end{array}$} & 30 & 96 & 66.33 & 65.68 & 52.57 & 80.87 & 6.52 \\
\hline & 50 & 55 & 66.39 & 65.05 & 56.75 & 95.92 & 7.09 \\
\hline & 70 & 96 & 70.73 & 71.35 & 58.89 & 85.79 & 6.22 \\
\hline & Total & 247 & 68.05 & 67.80 & 52.57 & 95.92 & 6.85 \\
\hline \multirow{4}{*}{$\begin{array}{c}6 \\
\text { Giżycko } \\
\text { FMBF }\end{array}$} & 30 & 96 & 67.99 & 67.26 & 52.25 & 85.55 & 6.73 \\
\hline & 50 & 96 & 72.05 & 72.16 & 56.37 & 88.91 & 6.79 \\
\hline & 70 & 96 & 71.51 & 71.17 & 57.28 & 88.42 & 6.42 \\
\hline & Total & 288 & 70.51 & 70.16 & 52.25 & 88.91 & 6.86 \\
\hline \multirow{4}{*}{$\begin{array}{c}7 \\
\text { Górowo } \\
\text { Iławeckie } \\
\text { FBF }\end{array}$} & 30 & 96 & 62.41 & 62.25 & 52.37 & 72.86 & 4.51 \\
\hline & 50 & 96 & 62.42 & 62.17 & 50.31 & 85.55 & 7.59 \\
\hline & 70 & 94 & 67.47 & 68.11 & 52.02 & 82.55 & 6.79 \\
\hline & Total & 286 & 64.08 & 63.31 & 50.31 & 85.55 & 6.83 \\
\hline \multirow{4}{*}{$\begin{array}{c}8 \\
\text { Elblag } \\
\text { FBF }\end{array}$} & 30 & 96 & 65.51 & 64.88 & 51.90 & 83.00 & 6.81 \\
\hline & 50 & 96 & 63.44 & 63.01 & 56.35 & 78.00 & 4.49 \\
\hline & 70 & 96 & 66.08 & 65.53 & 53.09 & 83.68 & 7.04 \\
\hline & Total & 288 & 65.01 & 64.09 & 51.90 & 83.68 & 6.30 \\
\hline \multirow{4}{*}{$\begin{array}{c}9 \\
\text { Mircze } \\
\text { FBF }\end{array}$} & 30 & 96 & 68.50 & 67.60 & 55.32 & 88.47 & 7.38 \\
\hline & 50 & 96 & 67.38 & 67.34 & 52.37 & 88.97 & 7.66 \\
\hline & 70 & 96 & 67.91 & 67.68 & 55.45 & 84.61 & 5.35 \\
\hline & Total & 288 & 67.93 & 67.51 & 52.37 & 88.97 & 6.87 \\
\hline \multirow{4}{*}{$\begin{array}{c}10 \\
\text { Bobolice } \\
\text { FBF }\end{array}$} & 30 & 95 & 62.07 & 61.71 & 50.35 & 72.16 & 4.61 \\
\hline & 50 & 96 & 63.50 & 63.09 & 55.43 & 79.42 & 4.69 \\
\hline & 70 & 96 & 63.76 & 63.33 & 52.68 & 78.99 & 5.16 \\
\hline & Total & 287 & 63.11 & 62.94 & 50.35 & 79.42 & 4.87 \\
\hline \multirow{4}{*}{$\begin{array}{c}11 \\
\text { Bobolice } \\
\text { FMBF }\end{array}$} & 30 & 90 & 62.90 & 62.63 & 49.23 & 74.27 & 5.16 \\
\hline & 50 & 95 & 62.55 & 62.47 & 47.42 & 79.64 & 6.11 \\
\hline & 70 & 95 & 68.37 & 67.49 & 54.53 & 83.45 & 7.72 \\
\hline & Total & 280 & 64.64 & 64.03 & 47.42 & 83.45 & 6.95 \\
\hline \multirow{4}{*}{$\begin{array}{c}12 \\
\text { Łobez } \\
\text { FBF }\end{array}$} & 30 & 87 & 59.57 & 59.80 & 50.01 & 68.88 & 4.60 \\
\hline & 50 & 96 & 70.00 & 69.33 & 51.03 & 88.78 & 8.83 \\
\hline & 70 & 96 & 71.53 & 71.51 & 57.42 & 81.62 & 4.93 \\
\hline & Total & 279 & 67.27 & 67.15 & 50.01 & 88.78 & 8.30 \\
\hline \multirow{4}{*}{$\begin{array}{c}13 \\
\text { Łobez } \\
\text { FMBF }\end{array}$} & 30 & 91 & 60.85 & 61.21 & 50.58 & 69.58 & 4.12 \\
\hline & 50 & 96 & 61.29 & 60.98 & 52.34 & 70.86 & 4.18 \\
\hline & 70 & 96 & 70.05 & 70.04 & 60.53 & 79.42 & 4.22 \\
\hline & Total & 283 & 64.12 & 63.67 & 50.58 & 79.42 & 5.95 \\
\hline \multirow{4}{*}{$\begin{array}{l}14 \\
\text { Lipinki } \\
\text { FBF }\end{array}$} & 30 & 89 & 62.91 & 63.30 & 52.60 & 71.98 & 4.97 \\
\hline & 50 & 96 & 67.28 & 67.18 & 54.22 & 80.87 & 6.22 \\
\hline & 70 & 96 & 68.00 & 68.05 & 55.64 & 77.81 & 4.95 \\
\hline & Total & 281 & 66.14 & 66.24 & 52.60 & 80.87 & 5.84 \\
\hline
\end{tabular}


Table A1. Cont.

\begin{tabular}{|c|c|c|c|c|c|c|c|}
\hline $\begin{array}{l}\text { Location- } \\
\text { Forest District }\end{array}$ & Tree Age & $\begin{array}{l}\text { Number of } \\
\text { Groups (N) }\end{array}$ & Mean & Median & Minimum & Maximum & $\begin{array}{c}\text { Standard } \\
\text { Deviation }\end{array}$ \\
\hline \multirow{4}{*}{$\begin{array}{c}15 \\
\text { Lipinki } \\
\text { FMBF }\end{array}$} & 30 & 95 & 61.68 & 61.29 & 48.14 & 77.59 & 5.58 \\
\hline & 50 & 96 & 69.84 & 70.02 & 51.88 & 81.54 & 6.01 \\
\hline & 70 & 96 & 70.92 & 71.88 & 53.22 & 86.28 & 6.77 \\
\hline & Total & 287 & 67.50 & 68.14 & 48.14 & 86.28 & 7.38 \\
\hline \multirow{4}{*}{$\begin{array}{c}16 \\
\text { Rudziniec } \\
\text { FBF }\end{array}$} & 30 & 96 & 59.38 & 58.68 & 45.47 & 74.30 & 5.50 \\
\hline & 50 & 96 & 65.52 & 65.74 & 51.64 & 80.20 & 4.97 \\
\hline & 70 & 96 & 66.63 & 67.10 & 52.36 & 76.34 & 5.69 \\
\hline & Total & 288 & 63.84 & 64.20 & 45.47 & 80.20 & 6.26 \\
\hline \multirow{4}{*}{$\begin{array}{c}17 \\
\text { Rudziniec } \\
\text { FMBF }\end{array}$} & 30 & 95 & 69.48 & 69.86 & 52.49 & 90.62 & 8.66 \\
\hline & 50 & 96 & 62.99 & 63.32 & 47.44 & 74.51 & 6.60 \\
\hline & 70 & 96 & 68.77 & 69.04 & 57.34 & 89.03 & 6.24 \\
\hline & Total & 287 & 67.07 & 67.00 & 47.44 & 90.62 & 7.78 \\
\hline \multirow{2}{*}{\multicolumn{2}{|c|}{$\begin{array}{c}\text { FBF } \\
\text { FMBF }\end{array}$}} & 3352 & 66.04 & 65.44 & 45.47 & 95.92 & 6.90 \\
\hline & & 1425 & 66.79 & 66.28 & 47.42 & 90.62 & 7.37 \\
\hline \multicolumn{2}{|l|}{ Age 30} & 1571 & 64.63 & 63.92 & 45.47 & 90.62 & 6.81 \\
\hline \multicolumn{2}{|l|}{ Age 50} & 1583 & 66.05 & 65.16 & 47.42 & 95.92 & 7.40 \\
\hline \multicolumn{2}{|l|}{ Age 70} & 1623 & 68.05 & 68.02 & 51.08 & 89.73 & 6.49 \\
\hline \multicolumn{2}{|l|}{ Total } & 4777 & 66.26 & 65.68 & 45.47 & 95.92 & 7.05 \\
\hline
\end{tabular}

Table A2. Characteristics of Brinell hardness of silver birch wood on a radial section (MPa).

\begin{tabular}{|c|c|c|c|c|c|c|c|}
\hline $\begin{array}{c}\text { Location- } \\
\text { Forest District }\end{array}$ & Tree Age & $\begin{array}{l}\text { Number of } \\
\text { Groups (N) }\end{array}$ & Mean & Median & Minimum & Maximum & $\begin{array}{l}\text { Standard } \\
\text { Deviation }\end{array}$ \\
\hline \multirow{4}{*}{$\begin{array}{c}1 \\
\text { Płońsk } \\
\text { FBF }\end{array}$} & 30 & 80 & 46.80 & 46.96 & 40.07 & 52.13 & 2.87 \\
\hline & 50 & 89 & 48.72 & 48.26 & 42.80 & 56.45 & 3.39 \\
\hline & 70 & 96 & 47.05 & 46.96 & 38.38 & 53.28 & 2.88 \\
\hline & Total & 265 & 47.54 & 47.35 & 38.38 & 56.45 & 3.17 \\
\hline \multirow{4}{*}{$\begin{array}{l}2 \\
\text { Sokołów } \\
\text { FBF }\end{array}$} & 30 & 93 & 50.52 & 50.36 & 43.42 & 58.79 & 3.21 \\
\hline & 50 & 96 & 50.14 & 50.36 & 41.87 & 55.32 & 2.84 \\
\hline & 70 & 96 & 48.51 & 48.72 & 39.29 & 54.95 & 3.38 \\
\hline & Total & 285 & 49.71 & 49.82 & 39.29 & 58.79 & 3.26 \\
\hline \multirow{4}{*}{$\begin{array}{c}3 \\
\text { Biała Podlaska } \\
\text { FBF }\end{array}$} & 30 & 87 & 47.40 & 47.63 & 39.83 & 54.16 & 2.91 \\
\hline & 50 & 96 & 48.59 & 47.94 & 39.99 & 56.53 & 3.48 \\
\hline & 70 & 90 & 48.62 & 48.51 & 43.79 & 55.30 & 2.47 \\
\hline & Total & 273 & 48.22 & 48.14 & 39.83 & 56.53 & 3.04 \\
\hline \multirow{4}{*}{$\begin{array}{c}4 \\
\text { Płaska } \\
\text { FBF }\end{array}$} & 30 & 93 & 47.30 & 47.16 & 38.42 & 59.85 & 3.56 \\
\hline & 50 & 96 & 45.56 & 45.40 & 36.23 & 57.41 & 4.43 \\
\hline & 70 & 96 & 45.63 & 45.06 & 33.75 & 63.65 & 5.75 \\
\hline & Total & 285 & 46.15 & 46.27 & 33.75 & 63.65 & 4.73 \\
\hline \multirow{4}{*}{$\begin{array}{c}5 \\
\text { Giżycko } \\
\text { FBF }\end{array}$} & 30 & 96 & 47.38 & 48.07 & 38.80 & 55.23 & 3.67 \\
\hline & 50 & 55 & 48.19 & 48.28 & 38.57 & 60.42 & 4.24 \\
\hline & 70 & 96 & 49.55 & 49.22 & 39.42 & 60.28 & 4.12 \\
\hline & Total & 247 & 48.40 & 48.49 & 38.57 & 60.42 & 4.08 \\
\hline \multirow{4}{*}{$\begin{array}{c}6 \\
\text { Giżycko } \\
\text { FMBF }\end{array}$} & 30 & 96 & 44.20 & 44.13 & 35.97 & 53.09 & 3.92 \\
\hline & 50 & 96 & 47.78 & 47.92 & 40.14 & 57.41 & 3.82 \\
\hline & 70 & 96 & 49.10 & 48.91 & 40.54 & 59.71 & 3.69 \\
\hline & Total & 288 & 47.03 & 47.16 & 35.97 & 59.71 & 4.33 \\
\hline \multirow{4}{*}{$\begin{array}{c}7 \\
\text { Górowo } \\
\text { Iławeckie } \\
\text { FBF }\end{array}$} & 30 & 96 & 43.70 & 43.76 & 35.35 & 54.43 & 3.30 \\
\hline & 50 & 96 & 43.87 & 44.32 & 32.42 & 54.81 & 4.34 \\
\hline & 70 & 94 & 45.93 & 45.56 & 39.11 & 52.61 & 3.33 \\
\hline & Total & 286 & 44.49 & 44.46 & 32.42 & 54.81 & 3.82 \\
\hline \multirow{4}{*}{$\begin{array}{c}8 \\
\text { Elbląg } \\
\text { FBF }\end{array}$} & 30 & 96 & 42.78 & 42.59 & 35.55 & 58.92 & 3.94 \\
\hline & 50 & 96 & 43.22 & 43.44 & 33.55 & 50.19 & 2.91 \\
\hline & 70 & 96 & 42.90 & 42.99 & 35.55 & 49.10 & 2.95 \\
\hline & Total & 288 & 42.97 & 43.03 & 33.55 & 58.92 & 3.30 \\
\hline
\end{tabular}


Table A2. Cont.

\begin{tabular}{|c|c|c|c|c|c|c|c|}
\hline $\begin{array}{l}\text { Location- } \\
\text { Forest District }\end{array}$ & Tree Age & $\begin{array}{l}\text { Number of } \\
\text { Groups (N) }\end{array}$ & Mean & Median & Minimum & Maximum & $\begin{array}{l}\text { Standard } \\
\text { Deviation }\end{array}$ \\
\hline \multirow{4}{*}{$\begin{array}{c}9 \\
\text { Mircze } \\
\text { FBF }\end{array}$} & 30 & 96 & 42.64 & 42.81 & 36.12 & 49.53 & 2.54 \\
\hline & 50 & 96 & 43.82 & 43.31 & 35.55 & 54.43 & 3.55 \\
\hline & 70 & 96 & 44.41 & 44.74 & 38.03 & 51.21 & 2.93 \\
\hline & Total & 288 & 43.62 & 43.53 & 35.55 & 54.43 & 3.11 \\
\hline \multirow{4}{*}{$\begin{array}{c}10 \\
\text { Bobolice } \\
\text { FBF }\end{array}$} & 30 & 95 & 40.17 & 40.34 & 30.97 & 45.59 & 2.81 \\
\hline & 50 & 96 & 40.06 & 40.25 & 34.90 & 46.59 & 2.46 \\
\hline & 70 & 96 & 41.49 & 41.66 & 33.63 & 49.45 & 2.78 \\
\hline & Total & 287 & 40.58 & 40.67 & 30.97 & 49.45 & 2.76 \\
\hline \multirow{4}{*}{$\begin{array}{c}11 \\
\text { Bobolice } \\
\text { FMBF }\end{array}$} & 30 & 90 & 41.31 & 41.22 & 32.60 & 49.56 & 2.97 \\
\hline & 50 & 95 & 40.30 & 40.84 & 31.44 & 48.69 & 3.08 \\
\hline & 70 & 95 & 42.61 & 42.94 & 32.05 & 54.91 & 3.94 \\
\hline & Total & 280 & 41.41 & 41.44 & 31.44 & 54.91 & 3.49 \\
\hline \multirow{4}{*}{$\begin{array}{c}12 \\
\text { Łobez } \\
\text { FBF }\end{array}$} & 30 & 87 & 38.70 & 38.48 & 31.86 & 46.59 & 3.23 \\
\hline & 50 & 96 & 43.80 & 43.91 & 36.30 & 51.73 & 3.23 \\
\hline & 70 & 96 & 43.20 & 42.99 & 36.89 & 52.56 & 2.72 \\
\hline & Total & 279 & 42.00 & 42.14 & 31.86 & 52.56 & 3.79 \\
\hline \multirow{4}{*}{$\begin{array}{c}13 \\
\text { Łobez } \\
\text { FMBF }\end{array}$} & 30 & 91 & 41.10 & 41.14 & 32.72 & 46.99 & 2.58 \\
\hline & 50 & 96 & 40.93 & 40.93 & 34.97 & 47.10 & 2.58 \\
\hline & 70 & 96 & 43.03 & 42.72 & 36.81 & 49.01 & 2.54 \\
\hline & Total & 283 & 41.70 & 41.53 & 32.72 & 49.01 & 2.73 \\
\hline \multirow{4}{*}{$\begin{array}{c}14 \\
\text { Lipinki } \\
\text { FBF }\end{array}$} & 30 & 89 & 40.34 & 40.58 & 33.75 & 49.68 & 2.89 \\
\hline & 50 & 96 & 42.31 & 42.65 & 35.46 & 49.68 & 2.79 \\
\hline & 70 & 96 & 42.14 & 42.01 & 35.60 & 50.82 & 2.60 \\
\hline & Total & 281 & 41.63 & 41.62 & 33.75 & 50.82 & 2.89 \\
\hline \multirow{4}{*}{$\begin{array}{c}15 \\
\text { Lipinki } \\
\text { FMBF }\end{array}$} & 30 & 95 & 39.85 & 39.82 & 31.23 & 47.50 & 3.28 \\
\hline & 50 & 96 & 42.37 & 42.24 & 36.47 & 51.29 & 2.61 \\
\hline & 70 & 96 & 42.71 & 42.74 & 36.84 & 50.59 & 2.59 \\
\hline & Total & 287 & 41.65 & 41.79 & 31.23 & 51.29 & 3.11 \\
\hline \multirow{4}{*}{$\begin{array}{c}16 \\
\text { Rudziniec } \\
\text { FBF }\end{array}$} & 30 & 96 & 39.64 & 39.66 & 34.06 & 45.78 & 2.20 \\
\hline & 50 & 96 & 41.94 & 42.19 & 35.89 & 47.71 & 2.58 \\
\hline & 70 & 96 & 41.76 & 41.53 & 36.47 & 47.82 & 2.60 \\
\hline & Total & 288 & 41.11 & 41.08 & 34.06 & 47.82 & 2.67 \\
\hline \multirow{4}{*}{$\begin{array}{c}17 \\
\text { Rudziniec } \\
\text { FMBF }\end{array}$} & 30 & 95 & 41.92 & 41.95 & 35.16 & 48.86 & 2.75 \\
\hline & 50 & 96 & 40.61 & 40.63 & 31.06 & 47.13 & 3.12 \\
\hline & 70 & 96 & 42.59 & 42.68 & 36.92 & 52.12 & 2.58 \\
\hline & Total & 287 & 41.71 & 41.77 & 31.06 & 52.12 & 2.93 \\
\hline \multicolumn{2}{|l|}{ FBF } & 3352 & 44.63 & 44.35 & 30.97 & 63.65 & 4.58 \\
\hline \multicolumn{2}{|l|}{ FMBF } & 1425 & 42.71 & 42.31 & 31.06 & 59.71 & 4.00 \\
\hline \multicolumn{2}{|l|}{ Age 30} & 1571 & 43.25 & 42.78 & 30.97 & 59.85 & 4.57 \\
\hline \multicolumn{2}{|l|}{ Age 50} & 1583 & 44.13 & 43.46 & 31.06 & 60.42 & 4.56 \\
\hline \multicolumn{2}{|l|}{ Age 70} & 1623 & 44.77 & 44.34 & 32.05 & 63.65 & 4.25 \\
\hline \multicolumn{2}{|l|}{ Total } & 4777 & 44.06 & 43.62 & 30.97 & 63.65 & 4.50 \\
\hline
\end{tabular}

\section{References}

1. Sydor, M. Drewno w Budowie Maszyn. Historia Najważniejszego Tworzywa, 1st ed.; Wydawnictwo Uniwersytetu Przyrodniczego: Poznań, Poland, 2011; pp. 38-45.

2. Kozakiewicz, P.; Noskowiak, A.; Pióro, P. Atlas Drewna Podłogowego, 1st ed.; Profi-Press: Warsaw, Poland, $2012 ;$ pp. 19-24.

3. Hertz, H.R. Über die Berührung fester elastischer Körper. J. Für Die Reine Angew. Math. 1881, 92, $156-171$.

4. Stieber, K.L. Technologja Drewna z Uwzględnieniem Kory, Łyka i Soków Drzewnych, 1st ed.; Księgarnia Polska B. Połonieckiego: Lviv and Warsaw, Poland, 1992; pp. 21-25.

5. Wróblewski, I.; De Mezer, K. Podręcznik Techniczny dla Stolarzy. Cz. 1. Zarys Materiałoznawstwa Drzewnego, 1st ed; PZWS: Warsaw, Poland, 1948.

6. Krzysik, F. Wood Science, 3rd ed.; PWN: Warsaw, Poland, 1978; pp. 582-591.

7. Joint Publication. Encyklopedia Techniki, 2nd ed.; Wydawnictwa Naukowo-Techniczne: Warsaw, Poland, 1994.

8. Koczan, G.; Karwat, Z.; Kozakiewicz, P. An attempt to unify the Brinell, Janka and Monnin hardness of wood on the basis of Meyer law. J. Wood Sci. 2021, 67, 1-16. [CrossRef] 
9. Riggio, M.; Piazza, M. Hardness Test. In In Situ Assessment of Structural Timber; Kasal, B., Tannert, T., Eds.; RILEM State of the Art Reports; Springer: Dordrecht, The Netherlands, 2010; Volume 7, pp. 87-97. [CrossRef]

10. Doyle, J.; Walker, J.C.F. Indentation hardness of wood. Wood Fibre. Sci. 1984, 17, 369-376.

11. Kubiak, M.; Laurow, Z. Surowiec Drzewny, 1st ed.; Fundacja Rozwój SGGW: Warsaw, Poland, 1994.

12. Gašparík, M.; Gaff, M.; Šafaříková, L.; Vallejo, C.R.; Svoboda, T. Impact bending strength and Brinell hardness of densified hardwoods. Bioresources 2016, 11, 8638-8652. [CrossRef]

13. Laskowska, A. The influence of process parameters on the density profile and hardness of surface-densified birch wood (Betula pendula Roth). Bioresources 2017, 12, 6011-6023. [CrossRef]

14. Antons, A.; Cirule, D.; Verovkins, A.; Kuka, E. Effect of thermal treatment on physical and mechanical properties of birch and pine wood. In Proceedings of the Research for Rural Development, 24th Annual International Scientific Conference on Research for Rural Development, Jelgava, Latvia, 16-18 May 2018; Volume 1, pp. 78-85. [CrossRef]

15. Borůvka, V.; Zeidler, A.; Holeček, T.; Dudík, R. Elastic and strength properties of heat-treated beech and birch wood. Forests 2018, 9, 197. [CrossRef]

16. Dudík, R.; Borůvka, V.; Zeidler, A.; Holeček, T.; Riedl, M. Influence of site conditions and quality of birch qood on its properties and utilization after heat treatment. Part II-Surface properties and marketing evaluation of the effect of the treatment on final usage of such wood. Forests 2020, 11, 556. [CrossRef]

17. Mania, P.; Wróblewski, M.; Wójciak, A.; Roszyk, E.; Moliński, W. Hardness of densified wood in relation to changed chemical composition. Forests 2020, 11, 506. [CrossRef]

18. Möttönen, V.; Heräjärvi, H.; Koivunen, H.; Lindblad, J. Influence of felling season, drying method and within-tree location on the brinell hardness and equilibrium moisture content of wood from 27-35- year-old Betula pendula. Scand. J. For. Res. 2004, 19, 241-249. [CrossRef]

19. Klisz, M.; Jastrzębowski, S.; Wojda, T.; Ukalska, J.; Noskowiak, A. Variability of black locust hardness in relation to different measurement direction and location along the stem. Wood Res. 2017, 62, 211-222.

20. Vakkari, P. 2009 Wytyczne ochrony i wykorzystania zasobów genowych brzozy brodawkowatej (Betula pendula Roth.). In European Forest Genetic Resources Programme (EUFORGEN); Beza, M.; Leśny Bank Genów Kostrzyca, Translators; European Forest Institute: Miłków, Poland, 2009; pp. 1-6.

21. Statistics Poland. Statistical Yearbook of Forestry; Zakład Wydawnictw Statystycznych: Warszawa, Poland, 2019.

22. Lachowicz, H.; Sajdak, M.; Paschalis-Jakubowicz, P.; Cichy, W.; Wojtan, R.; Witczak, M. The influence of location, tree ege and forest habitat type on basic fuel properties of the wood of the silver birch (Betula pendula Roth.) in Poland. BioEnergy Res. 2018, 11, 638-651. [CrossRef]

23. Lachowicz, H.; Paschalis-Jakubowicz, P.; Wojtan, R. Multivariate analysis of the variability in the density of oven-dry wood of silver birch (Betula pendula Roth.) in Poland. Drewno 2018, 61, 39-56. [CrossRef]

24. Lachowicz, H.; Bieniasz, A.; Wojtan, R. Variability in the basic density of silver birch wood in Poland. Silva Fenn. 2019, 53, 9968. [CrossRef]

25. Lachowicz, H.; Wróblewska, H.; Sajdak, M.; Komorowicz, M.; Wojtan, R. The chemical composition of silver birch (Betula pendula Roth.) wood in Poland depending on forest stand location and forest habitat type. Cellulose 2019, 26, 3047-3067. [CrossRef]

26. Lachowicz, H. Multivariate analysis of the variation of structural, physical and mechanical properties of silver birch (Betula pendula Roth.) wood. In Rozprawy Naukowe i Monografie; Wydawnictwo SGGW: Warsaw, Poland, 2015; pp. 39-56. [CrossRef]

27. Graves, H.S. Forest Mensuration; John Wiley \& Sons: New York, NY, USA, 1906.

28. Grochowski, J. Dendrometria; Powszechne Wydawnictwo Rolnicze i Leśne: Warsaw, Poland, 1973.

29. Bruchwald, A. Mathematical Statistics for Foresters; Wydawnictwo SGGW: Warsaw, Poland, 1989.

30. Stanisz, A. Accessible Course in Statistics with STATISTICA PL Application on Examples from Medicine, T. 1-3; StatSoft Polska: Cracow, Poland, 2006.

31. Kala, R. Statystyka dla Przyrodników; Wydawnictwo Uniwersytetu Przyrodniczego: Poznań, Poland, 2009.

32. TIBCO Software Inc. Statistica (Data Analysis Software System), Version 13. 2017. Available online: http:/ / statistica.io (accessed on 26 July 2021).

33. Wagenführ, R. Holzatlas; Fachbuchverlag Leipzig im; Carl Hanser Verlag: München, Germany, 2007.

34. Schwab, E. Die Härte von Laubhölzern für die Parkettherstellung. Holz Als Roh Werkst. 1990, 48, 47-51. [CrossRef]

35. Heräjärvi, H. Variation of basic density and Brinell hardness within mature finnish Betula pendula and P. pubescens stems. Wood Fieber Sci. 2004, 36, 216-227.

36. Bektas, I.; Alma, M.H.; As, N. Determination of the Relationships Between Brinell and Janka Hardness of Eastern Beech (Fagus orientalis L.). For. Prod. J. 2001, 51, 84-88. 